\title{
Hay and seed transfer to re-establish rare grassland species and communities: How important are date and soil preparation?
}

\author{
Armin Bischoff $^{\mathrm{a}, \mathrm{b}, *}$, Sandy Hoboy ${ }^{\mathrm{c}}$, Nadja Winter ${ }^{\mathrm{d}, \mathrm{e}}$, Guido Warthemann ${ }^{\mathrm{c}}$ \\ ${ }^{\text {a }}$ University of Avignon, Mediterranean Institute of Biodiversity and Ecology (IMBE, Aix-Marseille University, CNRS, IRD, University of Avignon), BP 61207, 84911 \\ Avignon, France \\ ${ }^{\mathrm{b}}$ University of Halle, Department of Geobotany and Botanical Garden, Am Kirchtor 1, 06108 Halle, Germany \\ ${ }^{\mathrm{c}}$ Environmental consultancy LPR Landschaftsplanung Dr. Reichhoff, Zur Großen Halle 15, 06844 Dessau-Roßlau, Germany \\ d Lower Nature Conservation Authority (UNB), Landkreis Wittenberg, Breitscheidstrasse 3, 06886 Wittenberg, Germany \\ e University of Applied Sciences Anhalt, Department of Agriculture, Ecotrophology and Landscape Development, Strenzfelder Allee 28, 06406 Bernburg, Germany
}

\section{A R T I C L E I N F O}

\section{Keywords:}

Cnidion meadow

Competition

Floodplain

Grassland restoration

Microsite limitation

Seedling recruitment

\begin{abstract}
A B S T R A C T
European floodplain grasslands are threatened by land use intensification or abandonment. Hay transfer using plant material from species-rich reference communities may be a valuable tool to restore such grasslands. However, large differences in seed production periods and strong competition are still obstacles that limit the efficiency of hay transfer. Using continental Cnidion meadows (FFH habitat type 6440) as a model system, we tested the effect of cutting date and of soil disturbance intensity on community and target species for eight years in a full-factorial hay transfer experiment.

The cutting date treatments were early (June), late (October), combined and no hay. Soil disturbance included shallow, deep and no tillage prior to hay transfer. We estimated the plant cover on donor and restoration sites before and after hay transfer. We additionally counted the individual number of seven specialist species of Cnidion meadows considered as target species. In a sowing experiment, seedling establishment was recorded for a subset of target species and compared to establishment in the hay transfer experiment.

Hay transfer was successful in transferring target species but community structure was still quite different from the reference grassland. Target species were only transferred with late hay but early hay added several nonspecialist species of Cnidion meadows. Strong competition by pre-existing vegetation prevented target species from establishing without soil disturbance but differences were small between shallow and deep tillage. In conclusion, a combination of early and late hay and moderate soil disturbance were the most appropriate treatments to restore Cnidion meadows.
\end{abstract}

\section{Introduction}

European floodplain grasslands are potentially diverse plant communities comprising many specialist plant species that do not or rarely occur in other grasslands (Joyce and Wade, 1998; Bischoff, 2002; Krause et al., 2011; Wesche et al., 2012). They are man-made but result from long-term traditional land use allowing an adaptation to this specific environment (Härdtle et al., 2006; Bischoff et al., 2009). However, recent changes in land use such as drainage, fertilization and the conversion to arable fields have degraded or destroyed these floodplain grassland communities (Hundt, 1996; Joyce and Wade, 1998; Krause et al., 2011). Specialists or indicator species have become rare and plant communities are usually protected now via European habitat directive such as the continental
Cnidion dubii meadows (habitat type 6440, FFH, 92/43/EEC; European Commission, 2007). Cnidion meadows can be found in Central and Eastern European river valleys from the French-German border to SouthWestern Siberia including the Rhine, Elbe, Danube and Oder floodplains and its tributaries (Šeffer et al., 2008; Ludewig et al., 2014).

In the Eastern German Elbe valley, intensification was particularly strong from the 1960s to 1980s since the former German Democratic Republic (GDR) aimed at self-sustainable food production resulting in a high conversion to arable land and increased livestock densities (Hundt, 1996; Warthemann and Reichhoff, 2001). After German reunification in 1990, agri-environment schemes were introduced to restore former species richness. The major objective of these schemes was to reduce fertilization and related grazing or cutting frequency to the traditional extensive level

* Corresponding author at: University of Avignon, Mediterranean Institute of Biodiversity and Ecology (IMBE, Aix-Marseille University, CNRS, IRD, University of Avignon), BP 61207, 84911 Avignon, France.

E-mail addresses: armin.bischoff@univ-avignon.fr (A. Bischoff), sandy.hoboy@lpr-landschaftsplanung.com (S. Hoboy), nadja.winter@landkreis-wittenberg.de (N. Winter), guido.warthemann@lpr-landschaftsplanung.com (G. Warthemann). 
through land use contracts with farmers. However, restoration success was poor in grasslands that did not include remnant populations of specialist floodplain grassland species (Bischoff, 2002; Bischoff et al., 2009). Grassland restoration is often dispersal limited and may be unsuccessful if source populations are too far away (Bischoff, 2000; Donath et al., 2003; Bischoff et al., 2009).

To overcome dispersal limitation, an active introduction of grassland species propagules has been suggested by several authors (Kiehl et al., 2010; Scotton et al., 2012). The use of seed mixtures involves propagation in stock by commercial producers. Seeds of less common species such as specialists of floodplain grasslands are usually not available. The transfer of hay collected in close-by reference communities may be a cost-efficient alternative to seed production (Kiehl et al., 2010). Although different techniques have been used to concentrate seeds in the cuttings, the transfer of green fresh hay is still the most widespread method and has also been successfully tested in floodplain grasslands (Donath et al., 2007; Edwards et al., 2007; Klimkowska et al., 2007; Engst et al., 2016).

Two problems may, however, limit the success of floodplain grassland restoration by hay transfer. First, seedling recruitment may be hampered by pre-existing grassland swards of already established species (Donath et al., 2007; Pywell et al., 2007; Schmiede et al., 2012). Due to the higher nutrient and water availability, productivity and interspecific competition are much higher than in dry or calcareous grasslands (Bischoff et al., 2009; Kiehl et al., 2010). In the Rhine valley, restoration by hay transfer was therefore more efficient starting from bare soil (arable fields) than from established grasslands (Donath et al., 2007). In the latter case, soil or sward disturbance may be required to improve restoration success (Schmiede et al., 2012).

Second, the phenology of floodplain grassland species is quite different resulting in different ripening periods. Early species may have already shed seed when late species start to produce seeds resulting in incomplete species assemblages if hay is only cut once (Kiehl et al., 2006; Edwards et al., 2007). Multiple transfers with plant material harvested at different dates are required to include early and late fruiting species but the thicker litter layer of multiple transfers may hamper germination (Kiehl et al., 2006; Scotton et al., 2012).

In this study, we used a full factorial experiment to test the influence of soil preparation and of harvest date on the efficiency of green hay transfer. While Schmiede et al. (2012) obtained similar seedling establishment for deep tillage by ploughing than for medium disturbance by rotovation, Schnoor et al. (2015) recommend rotovating rather than ploughing in calcareous grassland restoration. We used shallow and deep soil tillage to evaluate the need for sward opening or destruction prior to hay transfer. We combined these soil tillage treatments with hay transfer at different dates. Most specialist species of Cnidion meadows only produce seeds in late summer following regrowth after the first cut (Šeffer et al., 2008; Warthemann et al., 2009). Other typical but more widespread species flower much earlier and shed seeds before summer. We tested an early transfer corresponding to a traditional first cut, an early autumn transfer corresponding to a late second cut and a multiple transfer combining both. We hypothesised that specialist Cnidion species best establish from a late hay transfer whereas a full species set can only be obtained by transferring early and late hay. We additionally sowed hand-collected seeds of four specialist species to analyse seedling recruitment more in detail and to compare establishment from sown seeds and from hay.

We present classical community-based comparisons of reference and restoration grasslands but we focus on the re-establishment of target species populations because the protection of these species is a major aim of Cnidion meadow conservation. We specifically analyse the following research questions: i) Is hay transfer a suitable method to restore subcontinental floodplain grasslands and is it as efficient as hand sowing? ii) Can specialist (=target) species of Cnidion meadows be established and do their populations increase in the long run? iii) What is the best harvest time for transfer and are multiple transfers required? iv) Does previous soil disturbance improve re-establishment?

\section{Material and methods}

\subsection{Study site}

The experimental site is part of the "Neue Wiesen" grassland area $5 \mathrm{~km}$ west of Dessau ( $\left.51^{\circ} 51^{\prime} 09.9^{\prime \prime} \mathrm{N}, 12^{\circ} 08^{\prime} 45.5^{\prime \prime} \mathrm{E}\right)$. In the 1970s, large parts of this area were ploughed and re-sown using a species-poor grass mixture, followed by a period of intensive grassland use until the breakdown of the former GDR in 1989 (Warthemann et al., 2009). Since 1993, most of these grasslands have been under agri-environment schemes excluding fertiliser use, soil tillage and re-sowing. At the beginning of our experiment, after fourteen years of restoration, on average 21 species were found in $50 \mathrm{~m}^{2}$ plots but re-colonisation by target species specialised on Cnidion meadows was very low. Only some Silaum silaus individuals occurred before hay transfer ( $5 \%$ of the plots, mean cover: $0.025 \%$ ). The area is frequently inundated in spring after snowmelt in the surrounding mountain ranges, but flooding may also occur during summer following heavy rainfall in large parts of the river catchment. The site is only $1.25 \mathrm{~m}$ above the level of the next channel connecting the area with the Elbe River (Bischoff et al., 2009). Ground water levels may still decrease to $1.5 \mathrm{~m}$ below the surface during summer. $\mathrm{pH}$-values are about 6.4, plant available $\mathrm{N}$ (ammonium, nitrate), $\mathrm{P}$ and $\mathrm{K}$ contents of the soils are $0.5 \mathrm{mg} 100 \mathrm{ml}^{-1}, 4.4 \mathrm{mg}$

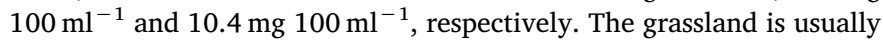
mown twice a year, mid-June and early September.

A close-by $(1 \mathrm{~km})$ Cnidion meadow of the same altitude was used as a reference and donor site for hay transfer. Seven target species described as regional specialist species of this plant community (Schubert et al., 2001) were identified on the reference site: Allium angulosum, Cnidium dubium, Galium boreale, Pseudolysimachium longifolium, Sanguisorba officinalis, Selinum carvifolia and Silaum silaus. Compared with a large-scale analysis of 33 grassland6s in the same region (Bischoff et al., 2009), only one target species (Serratula tinctoria) was missing.

\subsection{Experimental design}

\subsubsection{Green hay transfer}

The experiment was set up in June 2007 using a randomised block design. Each of the five replicate blocks comprised twelve treatment combinations and two replicates of each treatment combination resulting in 24 plots per block and 120 plots in total. Plot size was $5 \mathrm{~m} \times 10 \mathrm{~m}$. Prior to hay transfer the three soil disturbance treatments were established. Shallow tillage was realised using a rotary harrow that cuts rhizomes at the soil surface $(10 \mathrm{~cm})$ but not in deeper soil layers. A deep cultivator was used to destroy below-ground plant organs to a depth of $20-25 \mathrm{~cm}$ by deep tillage. One third of the plots were left undisturbed (control). At the following day (18 June, early transfer), hay was cut in a close-by reference community $(1 \mathrm{~km})$ and directly (without drying) transferred to the restoration plots (green hay). For this purpose, a bar-mower suction combination was used throwing the hay automatically on a loader wagon. The green hay was manually spread to the early hay and the combined hay plots representing half of the block area. In two of the five blocks, wild boar grubbing in deep and shallow tillage plots resulted in a second unintended soil disturbance. Hay transfer was repeated at 4 October 2007 by spreading the harvested material $\left(210 \mathrm{~g} \mathrm{~m}^{-2}\right)$ to the late hay and the combined hay plots resulting in four different hay transfer treatments: no hay (control), early hay, late hay and combined hay. The position of the twelve treatment combinations was randomised within blocks. Hay was collected from a reference site that was four times larger than the sum of the recipient plots (donor-recipient area ratio 4:1) resulting in a transferred layer of $596 \mathrm{~g}$ hay per $\mathrm{m}^{2}$ (air-dried before weighing).

\subsubsection{Transfer of hand-collected seeds}

One week after the late hay transfer, hand-collected seeds of four target species were sown to three additional plots in each block. To avoid cross contamination a buffer strip of $2 \mathrm{~m}$ separated sowing and hay 
transfer experiment. Similar soil disturbance treatments (no, shallow, deep tillage) were established prior to sowing using a rototiller and adjusting it for different depths. For the deep tillage treatment, the soil was tilled twice. Compared to the hay transfer experiment plot size was reduced to $5 \mathrm{~m} \times 5 \mathrm{~m}$ in order to obtain a sufficient seed density. The four selected target species were A. angulosum, C. dubium, S. officinalis and S. tinctoria. Seeds were collected within a distance of $60 \mathrm{~km}$ from source populations of different reference communities. They were manually separated from fruits and sown by hand in a density of 2400 seeds per plot ( 96 seeds $\mathrm{m}^{-2}$ ). For Sanguisorba officinalis, seed density was only 600 per plot $\left(24 \mathrm{~m}^{-2}\right)$ since less seeds were available.

\subsection{Measurements and observations}

The vegetation of the reference community was analysed in 2007 prior to hay transfer. The cover of all vascular plants was estimated in four randomly chosen quadrats of $100 \mathrm{~m}^{2}$. In order to evaluate seed transfer rates, the density of seeds was measured for three species: $C$. dubium, S. officinalis and Leucanthemum vulgare. L. vulgare is a typical species of floodplain grasslands but not a specialist Cnidion species since it occurs in different grassland communities. It was included in the analysis as a species that is predominantly transferred with early hay - contrary to the target species. The number of umbels (C. dubium) and flower heads (L. vulgare, $S$. officinalis) was counted in five representative $1 \mathrm{~m}^{2}$ quadrats. Fifty umbels and flower heads were sampled to count the number of seeds allowing an estimation of seed number per $\mathrm{m}^{2}$. This seed density of the reference community was compared to the seed density arriving on the restoration sites with the transferred hay. The seed density of the hay spread to the restoration sites was analysed using $1 \times 1 \mathrm{~m}^{2}$ cardboard seed traps. Five traps per block were placed on the ground prior to transfer. The hay samples were weighed after drying at ambient temperature. In five hay subsamples per block of together $100 \mathrm{~g}$, seeds were counted allowing the calculation of seed density per $\mathrm{m}^{2}$.

The vegetation of all plots of the experimental site was recorded in 2007 prior to transfer and soil disturbance, in 2008 and in 2011 using the same releve technique as in the reference community (estimation of cover $\%$ of all vascular plant species). Additionally the seven target species occurring at the reference site were counted. Due to their small size, seedlings were difficult to find in the beginning $(2008,2009)$ and we limited observations to three $1 \mathrm{~m}^{2}$ quadrats. In 2011 and 2015, the higher visibility of plants allowed an analysis of the whole plot area. The small seedling size also compromised the identification of different Apiaceae species in the first year (three target species and Daucus carota) Thus, 2008 seedling records were not taken into account in the present analyses. Seedling density of the sowing experiment was analysed in the same way and at the same date as in the hay transfer experiment.

\subsection{Data analyses}

Seed transfer rates for C. dubium, L. vulgare and $S$. officinalis were calculated for each block using seed density per $\mathrm{m}^{2}$ at source (reference community) and recipient sites (hay spread) divided by the area ratio: seed transfer rate $=\frac{\text { seed density (hay) } \mathrm{x} \text { area (recipient site) }}{\text { seed density (source) } \mathrm{x} \text { area (source site) }} \times 100$.

In order to calculate the average number of transferred species in each plot, species composition prior to transfer was compared with that after transfer and in the reference community. Species occurring after the transfer (2008 and 2011) were only considered as transferred if they occurred in the reference community but not in 2007 releves on the restoration sites prior to transfer. So, transferred species that occurred already before transfer as well as newly occurring species not found in the reference community were not taken into account. The latter case was quite common in the soil disturbance treatments since arable weeds absent from aboveground vegetation in previous releves emerged from the soil seed bank.
Univariate response variables such as species richness, number of transferred species and abundance of target species were analysed using generalised linear models (GLM). The hay transfer experiment model included the main effects of soil disturbance (three levels: no, shallow and deep tillage) and hay transfer treatment (four levels: no, early hay, late hay, combined hay), their interaction and the effect of block. Normally distributed response variables (with normally distributed residuals) were tested using Gaussian error with identity link function. The left-skewed data on number of transferred species and target species abundance were analysed using Poisson error with log-link function. In the case of overdispersion, the analyses were run with negative binomial errors and loglink function. A reduced model was applied to the sowing experiment only including soil disturbance and block effects. As in the hay transfer experiment a Poisson (not overdispersed) or negative binomial error (overdispersed) with log link function was used to analyse target species abundance. The glht function (multcomp package) in $\mathrm{R}$ (version 03.3.1, $\mathrm{R}$ Development Core Team (2013)) was used to run multiple comparisons within significant main effects or interactions.

Multivariate models were applied to analyse treatment effects on plant species composition. A Detrended Correspondence Analysis (DCA) was run to test whether a linear or a unimodal approach is better adapted to the data set. The gradient length was lower than three standard deviations, advocating for a linear approach (Ter Braak and Smilauer, 2012). A principal component analysis (PCA) was run to compare the species composition of all twelve treatments with that of the reference community. The effects of soil disturbance and hay transfer on plant species composition were tested using MANOVA. The model is the same as in the univariate analysis (two main effects, their interaction, block) but PseudoF statistics of partial Redundancy Analysis (RDA) modelled in Canoco 5 was used to evaluate significance. Different partial RDA were calculated to obtain Pseudo-F values for main effects, interaction and block as recommended by Ter Braak and Smilauer (2012). The different partial RDA models included one factor as explanatory variable whereas all other factors and interactions were fitted as co-variables. A full model including block as a covariate was calculated to obtain the residual variation. Except for multiple comparisons in GLM, Statistica 12 and Canoco 5 were used to run univariate and multivariate models, respectively.

\section{Results}

Except for Allium angulosum, all target species of the reference community were found on the restoration sites with hay transfer. With a mean cover of $<1 \%, A$. angulosum was quite rare in the reference community explaining the absence of this species. The quantitative analysis of transfer rates showed that losses are very different among species. The seed density of $S$. officinalis was low compared to the other analysed species $\left(41 \mathrm{~m}^{-2}\right)$ but the transfer rate was high $(85 \%$ of the reference community seeds, Fig. A1). C. dubium seed density on the recipient sites was $612 \mathrm{~m}^{-2}$ but transfer rate was only $15 \%$. And the non-target species L. vulgare occurred with highest seed densities $\left(930 \mathrm{~m}^{-2}\right)$ but showed an extremely low transfer rate (4\%) suggesting high losses during transfer.

In the first year, the hay transfer treatments had no significant influence on species richness but the influence of soil preparation was highly significant (Fig. 1A). The response to soil preparation was similar in all hay transfer treatments explained by the occurrence of annual species emerging from the soil seed bank such as Barbarea stricta, Capsella bursa-pastoris, Chenopodium polyspermum, Mentha arvensis, Myosotis arvensis, Polygonum aviculare and Rorippa palustris. These species disappeared until 2011 resulting in a non-significant soil disturbance effect on species richness in the fourth year after hay transfer (Fig. 1B). In this year, a significant hay transfer effect appeared with highest species richness in the combined hay treatment and lowest in the control without hay. The number of transferred species was in the first and in the fourth year positively influenced by previous soil disturbance and hay transfer. In the first year, transferred species number 
A

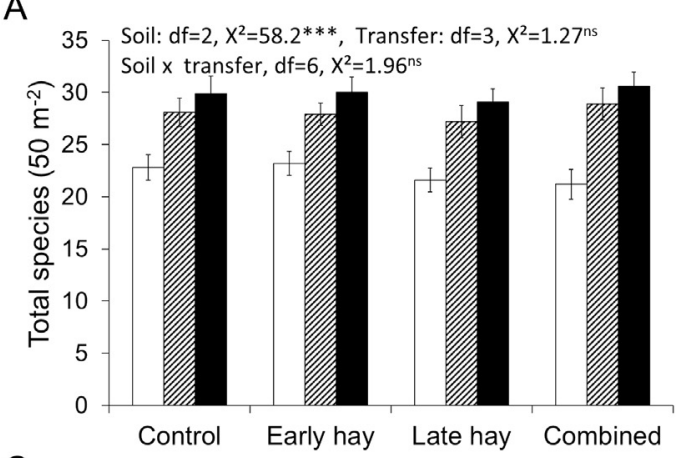

$\mathrm{C}$

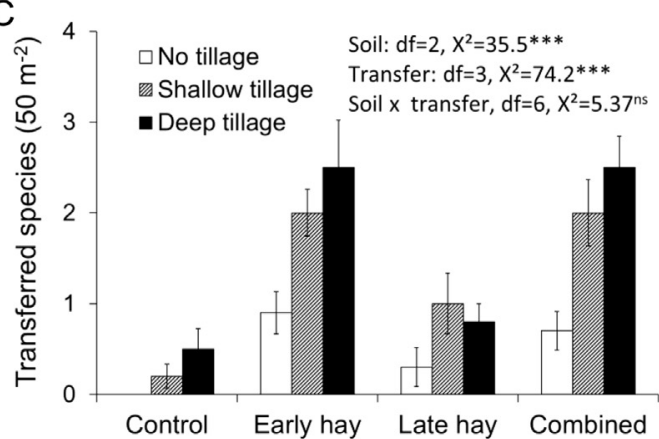

$\mathrm{B}$
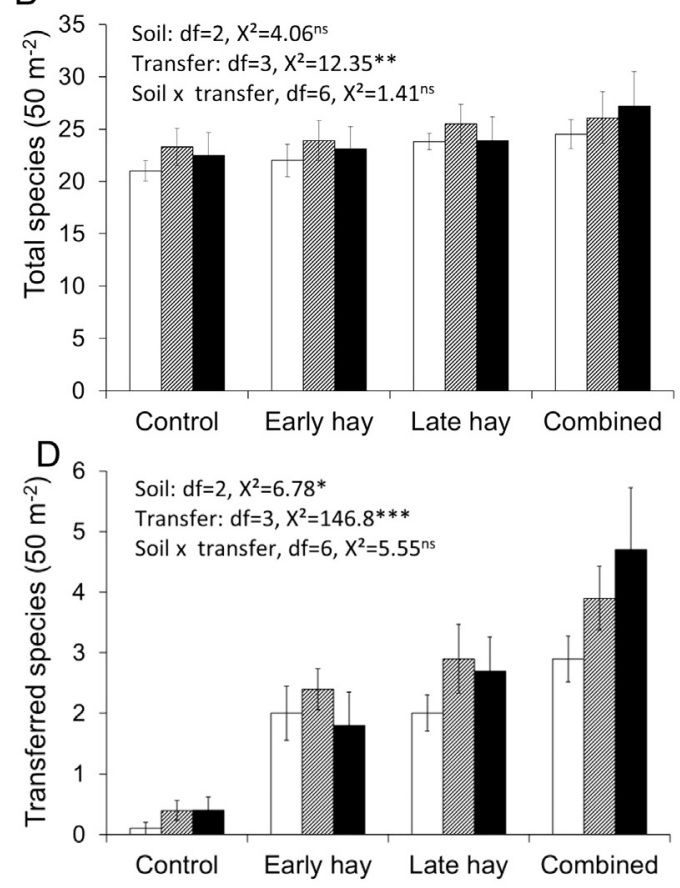

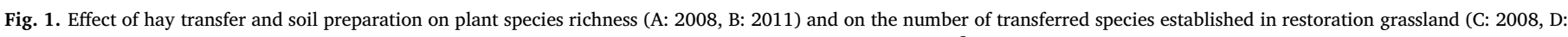

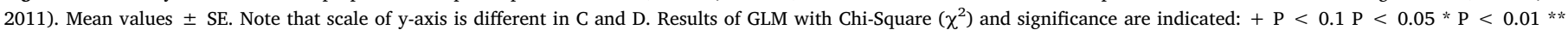
$\mathrm{P}<0.001^{* * *}$, ns: not significant.

Table 1

Multivariate analysis of variance comparing the effect of hay transfer and soil preparation on plant species composition of grassland restoration sites in the fourth year (2011).

\begin{tabular}{lllll}
\hline Factor & df & Total SS & Pseudo-F & P-value \\
\hline Block & 4 & 0.5681 & 46 & 0.002 \\
Transfer & 3 & 0.0459 & 5 & 0.002 \\
Soil & 2 & 0.0466 & 7.6 & 0.002 \\
Transfer $\times$ Soil & 6 & 0.0167 & 0.9 & 0.666 \\
Residual & 44 & 0.3227 & & \\
\hline
\end{tabular}

was highest in the early hay and the combined hay treatment (Fig. 1C). In the fourth year, this number largely increased in the late and the combined hay treatment whereas numbers remained unchanged in the control (close to 0) and in the early hay treatment (Fig. 1D). In the long

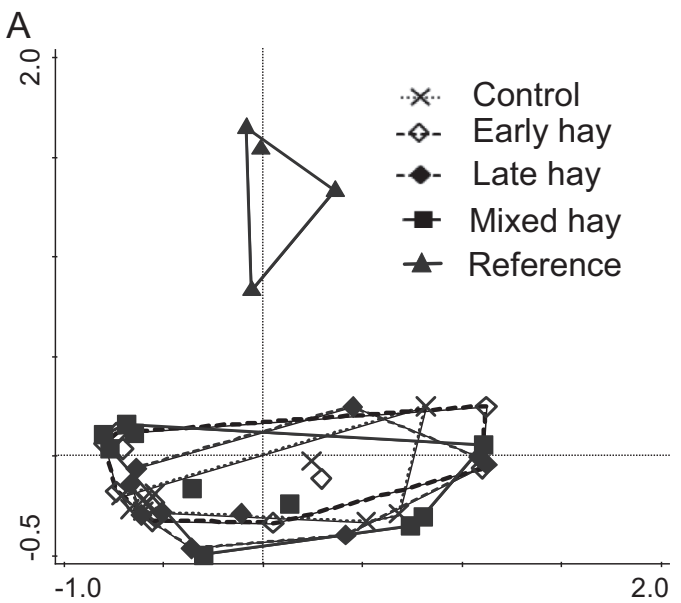

run, more species were transferred with the late than with the early hay and combined hay provided highest species numbers (significant to early hay: Tukey $\mathrm{P}=0.003$ ). The soil disturbance effect was explained by differences between the undisturbed control and the two tillage treatments (marginally significant to shallow tillage: Tukey $\mathrm{P}=0.060$ ) whereas no consistent difference was observed between deep and shallow tillage (Tukey $\mathrm{P}=0.446$ ).

Plant species composition in the fourth year was significantly affected by soil preparation and hay transfer (Table 1). The PCA plots showed that plant species composition of all restoration plots was still quite different from the reference community (Fig. 2). Without soil disturbance, no differences between hay transfer treatments can be identified (Fig. 2A). However, after deep tillage, the combined hay treatment and the late hay treatment were closer to the reference community than the early hay treatment and the control (Fig. 2B) indicating that in particular the transfer of late hay species is required to

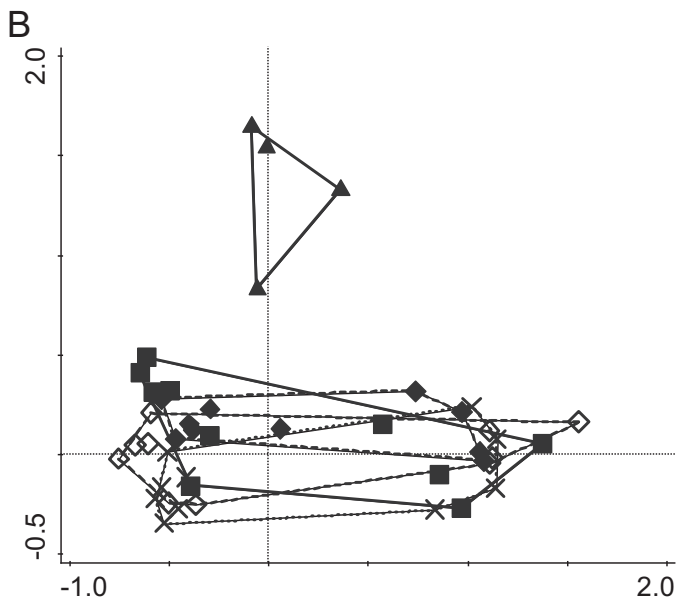

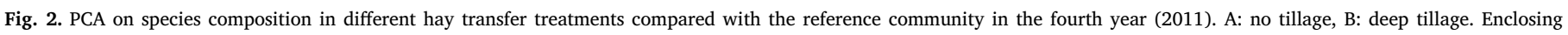
polygons are used to illustrate treatment positions in ordination space. 

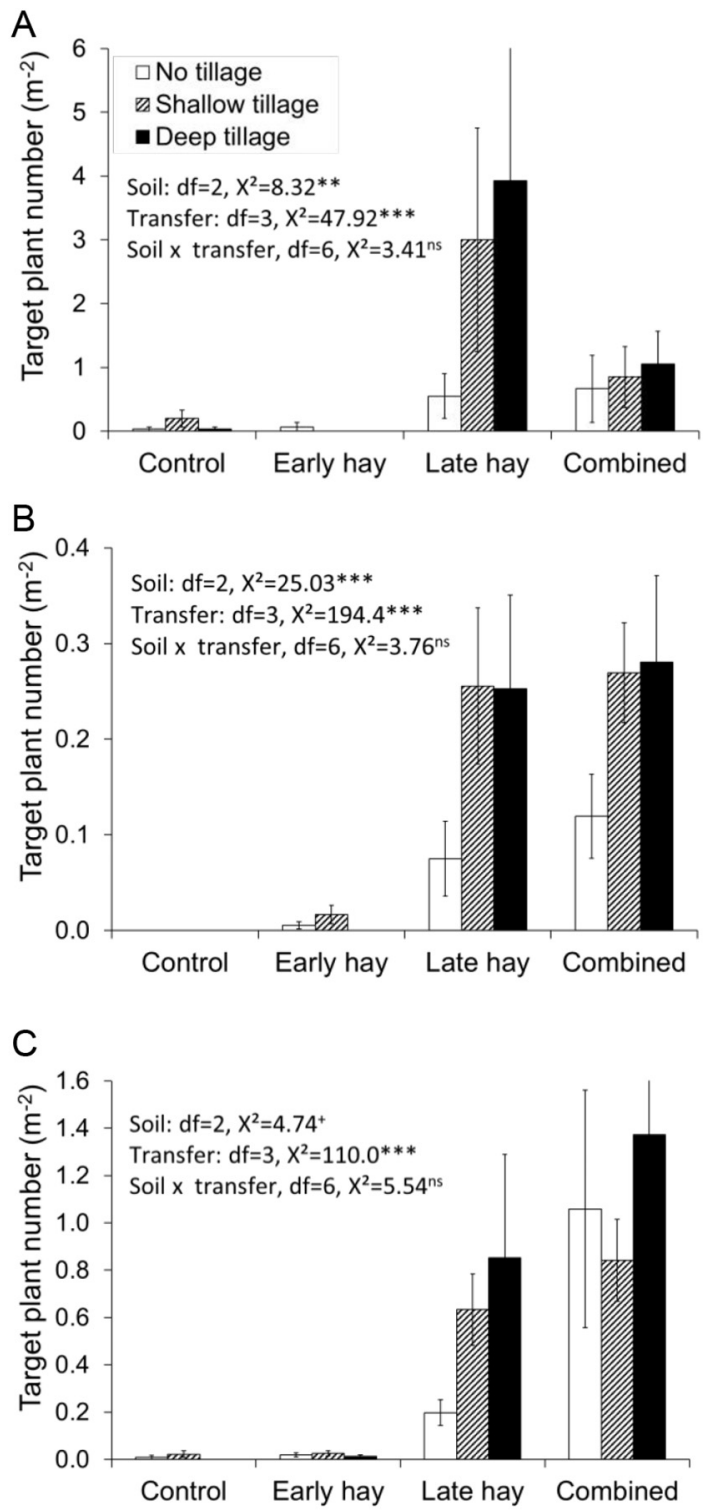

Fig. 3. Effect of hay transfer and soil preparation on the density of target species. A: 2009, B: 2011, C: 2015 . Mean values \pm SE. Note that scales of y-axis are different. Results of GLM with Chi-Square $\left(\chi^{2}\right)$ and significance are indicated: $+\mathrm{P}<0.1 \mathrm{P}<0.05$ * $\mathrm{P}<0.01 * * \mathrm{P}<0.001 * * *$, ns: not significant.

drive plant succession towards the reference system.

The abundance of target species clearly increased by late and combined hay transfer but not by early hay (Fig. 3, Tukey $\mathrm{P}<0.001$ for early vs. late hay/combined hay). Target species abundance was close to zero and not higher than in the control indicating that only late hay contained target species. In the first survey (second year), combined hay showed a lower target species abundance than late hay indicating a negative effect of the thicker litter layer (Fig. 3A). However, this difference disappeared in year four and eight (Fig. 3B,C). Soil tillage prior to hay transfer had a significantly positive influence on seedling recruitment of target species. However, the influence was not significant in the first survey (second year). Wild boar grubbing in two of the five blocks may have increased inter-block variation and seedling mortality in the beginning. In the fourth year, target species abundance was significantly higher in the shallow (Tukey $\mathrm{P}=0.019$ ) and deep tillage treatment (Tukey $\mathrm{P}=0.040$ ) compared with the undisturbed control whereas differences between the two tillage treatments were not significant. The positive effect of soil disturbance was still marginally significant in the eighths year (Fig. 3C). Target species abundance largely decreased from the second to the fourth year indicating high seedling mortality. However, abundance re-increased by the eighth year suggesting a secondary spread from established individuals. In Cnidium dubium and Sanguisorba officinalis, the seedling density was only 0.14 and $0.03 \mathrm{~m}^{-2}$ resulting in final establishment rates of $0.02 \%$ and $0.07 \%$, respectively, compared with seed densities in the transferred hay.

All four species of the sowing experiment got established but Allium angulosum was only found eight years after sowing and individual number (only four in total) was too low to analyse soil treatment effects. Seedling establishment rates of Cnidium dubium $(0.07 \%$ of sown seeds) and Sanguisorba officinalis ( $0.38 \%$ of sown seeds) were much higher in the sowing than in the hay transfer experiment. The best establishment was found for Serratula tinctoria $(0.57 \%)$ absent from the source community of the hay transfer. In these three species, soil tillage had a clearly positive effect on plant abundance confirming the result of the hay transfer experiment (Fig. 4). No C. dubium and very few $S$. officinalis individuals were found in controls without soil disturbance. While $S$. officinalis benefitted from a deep soil tillage the other species did not show consistent differences between shallow and deep tillage. As in the hay transfer experiment $C$. dubium abundance increased with time whereas $S$. officinalis abundance remained constant. $S$. tinctoria showed a decline in individual but was still the most successful species in year eight of the experiment.

\section{Discussion}

\subsection{Hay transfer to establish species rich Cnidion meadows}

The transfer of freshly cut, green hay was successful in transferring specialist species of Cnidion meadows considered as target species of nature conservation and restoration in the Middle Elbe region. All target species occurring with at least medium densities in the donor community established on the restoration grassland. Additionally, other less specialised species lacking on the restoration site were successfully transferred and contributed to the increase in species richness. Compared to other studies, the number of transferred species seems to be low (reviewed by Kiehl et al., 2010). However, most of the cited studies only indicated the total number of transferred species per site or do not include control plots without transfer. A similar increase in average species numbers was observed by Edwards et al. (2007). Engst et al. (2016) found a higher increase but started from lower species richness in the beginning.

The test on seed transfer rates demonstrated that high numbers of target species seeds arrived on restoration grassland. Seed density of Cnidium dubium and Leucanthemum vulgare in the hay was higher than average seed density per species in hay transfer studies on other European floodplain grasslands (Donath et al., 2007; Schmiede et al., 2012). However, transfer ratios that, to our knowledge, have not yet been tested in other studies were largely species-specific. Depending on ripeness and morphology, seeds may drop to the soil when touched by the mowing machines but there may also be losses during the transport. Seedling recruitment rates were low indicating strong competition by the already established vegetation. Final establishment rates relative to the number of sown seeds were also below $0.1 \%$ in eight floodplain grassland species tested in a similar plant community (Schmiede et al., 2013). Our study confirmed that in mesophilic systems such as floodplains, competition represents a particularly strong environmental filter that often limits the re-establishment of target species (Pywell et al., 2007; Bischoff et al., 2009; Schmiede et al., 2012).

Our study also demonstrated that long-term monitoring is required to evaluate restoration success. Several species were not (A. angulosum in the sowing experiment) or poorly (Cnidium dubium) visible in the beginning but occurred after eight years - in the case of $C$. dubium with a relatively high abundance. In general, a decline was observed in the beginning due to seedling mortality followed by a subsequent increase 
A

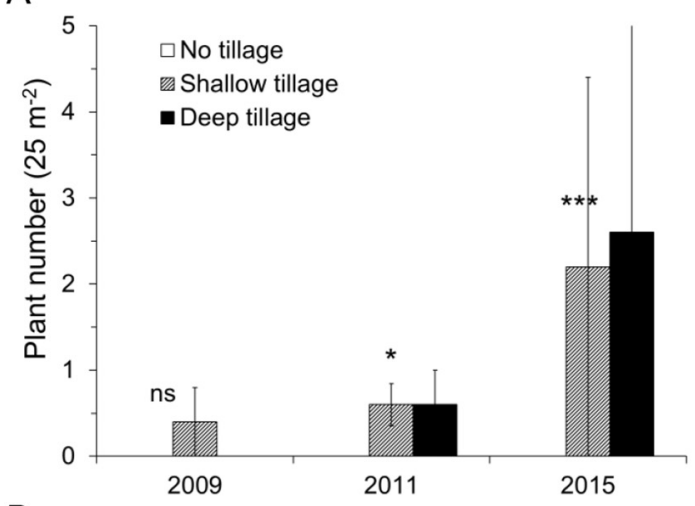

B

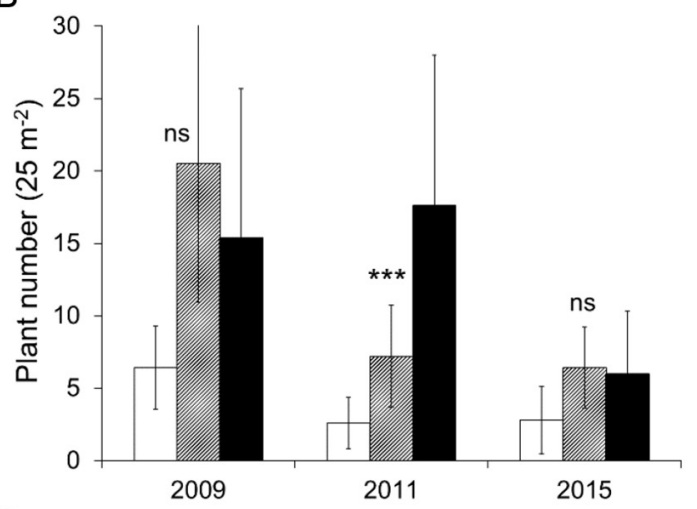

C

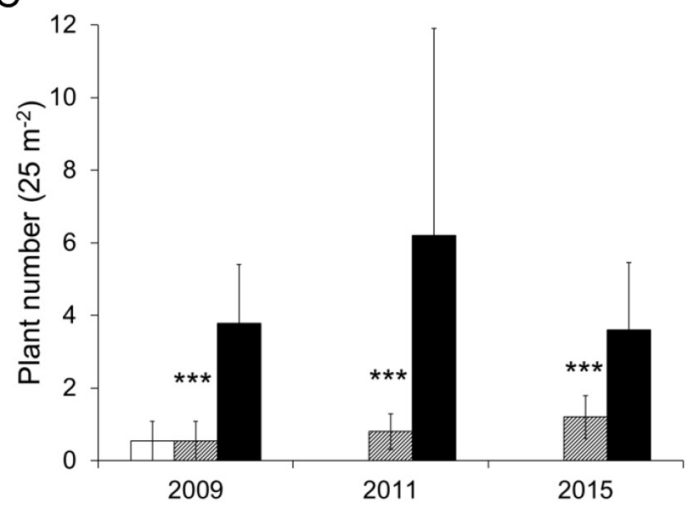

Fig. 4. Effect of soil preparation on the density of sown target species. A: Cnidium dubium, B: Serratula tinctoria, C: Sanguisorba officinalis. Mean values \pm SE. Note that scales of yaxis are different. Significance of soil disturbance effect (GLM) is indicated above columns: $\mathrm{P}<0.05 * \mathrm{P}<0.01 * * \mathrm{P}<0.001 * * *$, ns: not significant.

eight years after transfer. The increase may be explained by a low visibility of seedlings in the beginning (risk of overlooking) but also by a secondary spread through sexual reproduction or vegetative propagation. In particular, C. dubium shows a high small-scale turn-over with clonal growth from lateral roots forming short-lived monocarpic ramets (Geißler and Gzik, 2008). Once established, the species continuously produce such ramets that were counted as individuals in our study.

The establishment of target species tested in the sowing experiment and also occurring in the donor community of the hay transfer experiment (C. dubium, $S$. officinalis) was three to five times lower in the latter one. The non-reproductive biomass transferred with the hay may reduce germination and seedling recruitment (Eckstein and Donath, 2005; Hovstad and Ohlson, 2008; Schmiede et al., 2013). The most important factor is the reduction in light availability but also physical barrier effects and chemical litter compounds may hamper the establishment of plant species. Hovstad and Ohlson (2008) found inhibitory effects on germination and seedling growth already for litter amounts of
$400 \mathrm{~g} \mathrm{~m}^{-2}$ whereas facilitative effects prevailed in the study of Schmiede et al. (2013) up to $800 \mathrm{~g} \mathrm{~m}^{-2}$ under controlled conditions. In our study, potentially negative effects of litter were confirmed by a lower target species density in the combined hay treatment that received much more vegetative biomass (with the first hay) than the late hay treatment but the same amount of seeds.

\subsection{Date of cutting and transfer}

The date of hay transfer was crucial for the re-establishment of target species. Target species were almost absent in the first hay treatment. Due to their late flowering period, target species are usually unable to produce seeds until the first cutting date determined by the phenology of major grass species (Bischoff et al., 2009). Target species of Cnidion meadows typically flower and produce seeds in the aftermath when competition by high growing grasses is lower (Donath et al., 2007; Baasch et al., 2016). Aftermath cutting is therefore the better strategy to transfer target species and to improve the conservation value of such grasslands. It is also in agreement with agricultural use of the grasslands since quality and quantity of the first cutting are higher. However, aftermath grazing as the most common form of grassland use in the study region (Bischoff et al., 2009) needs to be limited.

Although the best strategy to re-establish Cnidion target species, the late hay transfer did not add all the species of the donor community that were lacking on the restoration sites. More widespread species not limited to Cnidion meadows such as Euphorbia esula, Leucanthemum vulgare and Ranunculus acris were predominantly transferred with the early hay. Accordingly, the average number of transferred species was still higher in the combined hay treatment than in the late hay treatment. Multiple transfers are useful if the phenology of plant species is very different (Kiehl et al., 2006; Scotton et al., 2012). In our study system, however, we observed a trade-off between an increase in species richness and a reduction in target species establishment due to the litter layer of the early hay (see above). Additionally, early hay may contain a high number of undesirable seed of highly competitive grasses that shed seed quite early in the season (Hölzel and Otte, 2003; Donath et al., 2006). Nevertheless, a multiple transfer of early and late hay is useful if restoration grassland is particularly species poor and/or if typical grass species are lacking.

\subsection{Previous soil tillage}

Soil tillage clearly increased the success of hay transfer treatments. The average number of transferred species as well as the abundance of target species was higher in plots that had been tilled prior to hay transfer. The sowing experiment confirmed this positive effect of soil tillage on seedling recruitment and establishment. The effect was stronger for the relatively small-seeded $C$. dubium than for $S$. officinalis and $S$. tinctoria with large seeds confirming the theory that small seeded seeds suffer more from competition and litter during seedling recruitment (Hölzel, 2005). However, even the large-seeded species benefitted significantly from soil disturbance.

At community level, hay transfer was only successful in changing plant species composition towards the reference community when soils were tilled before. Floodplains of lowland rivers receive high amounts of nutrients with inundation events resulting in a high productivity of floodplain grasslands (Bischoff et al., 2009; Ludewig et al., 2015). Microsite limitation increases with productivity and may hamper seedling recruitment (Pywell et al., 2007; Schmiede et al., 2012). Accordingly, restoration was more successful in Cnidion meadows of the upper Rhine valley when starting from bare ground on former arable fields than from existing species-poor grasslands (Donath et al., 2007). Similar positive effects of previous soil tillage on the re-establishment of grassland species and communities were shown in studies on nutrient poor calcareous grassland and in mesic lowland meadows (Edwards et al., 2007; Schmiede et al., 2012; Schnoor et al., 2015). In particular 
on lowland sites of high productivity, intensive soil disturbance by ploughing or turf stripping had a more positive effect on restoration success than shallow sward disturbance by harrowing or rotovation (Edwards et al., 2007; Schmiede et al., 2012) whereas on sandy, calcareous sites shallow rotovation provided the best results (Schnoor et al., 2015). In our study, deep tillage destroying rhizomes down to $25 \mathrm{~cm}$ favoured seedling recruitment and establishment but differences to shallow tillage by harrowing were small or absent in tested target species. Deep tillage, in particular ploughing has negative effects on soil erosion, nitrogen mineralisation (increase), soil structure, biological activity and diversity of soil organisms (Holland, 2004). A small advantage of deep tillage in terms of restoration success may not compensate for such negative effects.

\subsection{Conclusions}

Our study demonstrated that green hay transfer may be an appropriate technique to re-establish grassland communities of high conservation value including rare target species that are specialists of particular grassland types. However, success depended on date of hay making and on soil disturbance prior to hay transfer. In Cnidion meadows, target species produced seeds after the traditional first cutting date. Restoration of such meadows was thus only possible if the transferred plant material contained aftermath hay regrown after the first cut. Such late hay transfer is, however, not sufficient in transferring all species of the reference community. Species-poor restoration sites often need an additional early hay transfer to restore the typical community structure. In order to avoid negative effects of early hay litter layer on species emerging from late hay, late hay may be transferred to different areas resulting in a spatial separation of both treatments. Alternatively, a combination of hay transfer and sowing of seeds produced by local seed companies may be a more efficient solution if the phenology of few species does not correspond to the most appropriate cutting date (Baasch et al., 2016; Engst et al., 2016).

Hay transfer in productive lowland grassland needs soil disturbance to reduce competition. In particular, target species showed very poor seedling recruitment in undisturbed control plots. Such a destruction of pre-existing grassland sward needs to be tolerated in nature reserves and other protected areas. We only found a small advantage of deep tillage compared with shallow tillage not justifying the higher negative impact on soil structure and biota. Our study also confirmed that longterm monitoring is required to evaluate restoration success in productive grasslands (Auestad et al., 2016; Baasch et al., 2016). Within usual study periods of three to four years, results may be misleading since self-thinning due to seedling mortality reduced target plant number in the first years but later on secondary spread increased abundance.

Supplementary data to this article can be found online at https:// doi.org/10.1016/j.biocon.2018.02.033.

\section{Acknowledgements}

We thank Astrid Eichhorn (Word Wide Fund for Nature, WWF, Mittlere Elbe) and Hendrik Pannach (Biosphere Reserve Mittlere Elbe) for administrative support and information on field sites. Julia Knopf, Jeanne Poulet and Mathias Henning assisted in field surveys. The study was funded by the German Federal Agency for Nature Conservation (BfN), the WWF and the Federal State of Sachsen-Anhalt in the framework of the programme "large-scale conservation project (Naturschutzgrossprojekt) Mittlere Elbe"

\section{References}

Auestad, I., Rydgren, K., Austad, I., 2016. Near-natural methods promote restoration of species-rich grassland vegetation - revisiting a road verge trial after 9 years. Restor. Ecol. 24, 381-389.

Baasch, A., Engst, K., Schmiede, R., May, K., Tischew, S., 2016. Enhancing success in grassland restoration by adding regionally propagated target species. Ecol. Eng. 94, 583-591.

Bischoff, A., 2000. Dispersal and re-establishment of Silaum silaus in floodplain grasslands. Basic Appl. Ecol. 1, 129-131.

Bischoff, A., 2002. Dispersal and establishment of floodplain grassland species as limiting factors in restoration. Biol. Conserv. 104, 25-33.

Bischoff, A., Warthemann, G., Klotz, S., 2009. Succession of floodplain grasslands following reduction in land use intensity: the importance of environmental conditions, management and dispersal. J. Appl. Ecol. 46, 241-249.

Donath, T.W., Hölzel, N., Otte, A., 2003. The impact of site conditions and seed dispersal on restoration success in alluvial meadows. Appl. Veg. Sci. 6, 13-32.

Donath, T.W., Hölzel, N., Otte, A., 2006. Influence of competition by sown grass, disturbance and litter on recruitment of rare flood-meadow species. Biol. Conserv. 130, $315-323$.

Donath, T.W., Bissels, S., Hölzel, N., Otte, A., 2007. Large-scale application of diaspore transfer with plant material in restoration practice - impact of seed and microsite limitation. Biol. Conserv. 138, 224-234.

Eckstein, R.L., Donath, T.W., 2005. Interactions between litter and water availability affect seedling emergence in four familial pairs of floodplain species. J. Ecol. 93, $807-816$.

Edwards, A.R., Mortimer, S.R., Lawson, C.S., Westbury, D.B., Harris, S.J., Woodcock, B.A., Brown, V.K., 2007. Hay strewing, brush harvesting of seed and soil disturbance as tools for the enhancement of botanical diversity in grasslands. Biol. Conserv. 134, 372-382.

Engst, K., Baasch, A., Erfmeier, A., Jandt, U., May, K., Schmiede, R., Bruelheide, H., 2016. Functional community ecology meets restoration ecology: assessing the restoration success of alluvial floodplain meadows with functional traits. J. Appl. Ecol. 53, $751-764$.

European Commission, 2007. Interpretation Manual of European Union Habitats EUR 27. European Commission, Brussels.

Geißler, K., Gzik, A., 2008. Ramet demography and ecological attributes of the perennial river corridor plant Cnidium dubium (Schkuhr) Thell. (Apiaceae). Flora 203, 396-408.

Härdtle, W., Redecker, B., Assmann, T., Meyer, H., 2006. Vegetation responses to environmental conditions in floodplain grasslands: prerequisites for preserving plant species diversity. Basic Appl. Ecol. 7, 280-288.

Holland, J.M., 2004. The environmental consequences of adopting conservation tillage in Europe: reviewing the evidence. Agric. Ecosyst. Environ. 103, 1-25.

Hölzel, N., 2005. Seedling recruitment in flood-meadow species: the effects of gaps, litter and vegetation matrix. Appl. Veg. Sci. 8, 115-124.

Hölzel, N., Otte, A., 2003. Restoration of a species-rich flood-meadow by topsoil removal and diaspore transfer with plant material. Appl. Veg. Sci. 6, 131-140.

Hovstad, K.A., Ohlson, M., 2008. Physical and chemical effects of litter on plant establishment in semi-natural grasslands. Plant Ecol. 196, 251-260.

Hundt, R., 1996. Zur Veränderung der Wiesenvegetation Mitteldeutschlands unter dem Ein-fluß einer starken Bewirtschaftungsintensität. Berichte der Reinhold-TüxenGesellschaft 8, 127-143.

Joyce, C.B., Wade, P.M., 1998. European Wet Grasslands: Biodiversity, Management and Restoration. John Wiley, Chichester.

Kiehl, K., Thormann, A., Pfadenhauer, J., 2006. Evaluation of initial restoration measures during the restoration of calcareous grasslands on former arable fields. Restor. Ecol. 14, 148-156.

Kiehl, K., Kirmer, A., Donath, T.W., Rasran, L., Hölzel, N., 2010. Species introduction in restoration projects - evaluation of different techniques for the establishment of seminatural grasslands in central and North-Western Europe. Basic Appl. Ecol. 11, $285-299$.

Klimkowska, A., Van Diggelen, R., Bakker, J.P., Grootjans, A.P., 2007. Wet meadow restoration in Western Europe: a quantitative assessment of the effectiveness of several techniques. Biol. Conserv. 140, 318-328.

Krause, B., Culmsee, H., Wesche, K., Bergmeier, E., Leuschner, C., 2011. Habitat loss of floodplain meadows in north Germany since the 1950s. Biodivers. Conserv. 20, 2347-2364.

Ludewig, K., Korell, L., Löffler, F., Scholz, M., Mosner, E., Jensen, K., 2014. Vegetation patterns of floodplain meadows along the climatic gradient at the middle Elbe River. Flora 209, 446-455.

Ludewig, K., Donath, T.W., Zelle, B., Eckstein, R.L., Mosner, E., Otte, A., Jensen, K., 2015. Effects of reduced summer precipitation on productivity and forage quality of floodplain meadows at the Elbe and the Rhine River. PLoS One 10, e0124140.

Pywell, R.F., Bullock, J.M., Tallowin, J.R., Walker, K.J., Warman, E.A., Masters, G., 2007. Enhancing diversity of species-poor grasslands: an experimental assessment of multiple con-straints. J. Appl. Ecol. 44, 81-94.

R Development Core Team, 2013. R: A Language and Environment for Statistical Computing. R Foundation for Statistical Computing, Vienna, Austria.

Schmiede, R., Otte, A., Donath, T.W., 2012. Enhancing plant biodiversity in species-poor grassland through plant material transfer - the impact of sward disturbance. Appl. Veg. Sci. 15, 290-298.

Schmiede, R., Ruprecht, E., Eckstein, R.L., Otte, A., Donath, T.W., 2013. Establishment of rare flood meadow species by plant material transfer: experimental tests of threshold amounts and the effect of sowing position. Biol. Conserv. 159, 222-229.

Schnoor, T., Bruun, H.H., Olsson, P.A., 2015. Soil disturbance as a grassland restoration measure - effects on plant species composition and plant functional traits. PLoS One 10, e0123698.

Schubert, R., Hilbig, H., Klotz, S., 2001. Bestimmungsbuch der Pflanzengesellschaften Mittel- und Nordostdeutschlands. Spektrum Akademischer Verlag, Berlin.

Scotton, M., Kirmer, A., Krautzer, B., 2012. Practical Handbook for Seed Harvest and Ecological Restoration of Species-Rich Grasslands. Cleup Editore, Italy.

Šeffer, J., Janák, M., Šefferová Stanová, V., 2008. Management models for habitats in 
natura 2000 sites. In: 6440 Alluvial Meadows of River Valleys of the Cnidion dubii. European Commission, Brussels.

Ter Braak, C.J.F., Smilauer, P., 2012. CANOCO Reference Manual and User's Guide version 5.0. Biometrics. (Wageningen, Ceske Budejovice).

Warthemann, G., Reichhoff, L., 2001. Die Pflanzengesellschaften des Auengrünlandes im Biospärenreservat Mittlere Elbe (Sachsen-Anhalt) im historischen, räumlichen und syntaxo-nomischen Vergleich. Tuexenia 21, 153-178.
Warthemann, G., Winter, N., Bischoff, A., 2009. Renaturierung von BrenndoldenAuenwiesen durch Mahdgutübertragung in der Elbeaue bei Dessau. Naturschutz im Land Sachsen-Anhalt 46, Sonderheft 1 (Forschung und Management im Biosphärenreservat Mittelelbe). pp. 49-56.

Wesche, K., Krause, B., Culmsee, H., Leuschner, C., 2012. Fifty years of change in central European grassland vegetation: large losses in species richness and animal-pollinated plants. Biol. Conserv. 150, 76-85. 